\title{
Chinese silver grass Miscanthus sinensis (Poaceae): new alien species in the flora of Bosnia and Herzegovina
}

\author{
Semir Maslo1, Šemso Šarić ${ }^{2}$ Nermina Sarjlić3 \\ ${ }^{1}$ Primary School, Lundåkerskola, Gislaved, Sweden; semmas@edu.gislaved.se \\ 2Jelaške, Olovo, Bosnia and Herzegovina; semsosumar@gmail.com \\ ${ }^{3}$ Ornithological Society „Naše ptice“, Sarajevo, Bosnia and Herzegovina; nermina.sarajlic@ptice.ba
}

\begin{abstract}
Maslo S., Šarić Š., Sarjlić N. (2019): Chinese silver grass Miscanthus sinensis (Poaceae): new alien species in the flora of Bosnia and Herzegovina. - Thaiszia - J. Bot. 29 (1): 071-075.

Abstract: Chinese silver grass Miscanthus sinensis Andersson is native in southeastern Asia. It has been recorded as new to the vascular flora of Bosnia and Herzegovina, at two localities near the town of Zavidovići. The paper presents a short morphological description, photographs of the new alien species for Bosnia and Herzegovina, as well as the distribution of the taxon.

Keywords: alien plants, Bosnia and Herzegovina, distribution, Miscanthus, morphology.
\end{abstract}

\section{Introduction}

The genus Miscanthus Andersson belongs to the subtribe Saccharinae Griseb., tribe Andropogoneae Dumort., of Poaceae. There are about 14 species, which occur naturally in southeastern Asia and tropical Africa (Sun et al. 2010). Within the genus Miscanthus, only two species have been recorded as escapees in Europe Miscanthus sacchariflorus (Maxim.) Hack. and Miscanthus sinensis Andersson (Valdés \& Scholz 2009).

$M$. sacchariflorus is the most morphologically similar species to $M$. sinensis in Europe. To distinguish between these two species, we offer short determination key adapted according to Sun et al. (2010) and Verloove (2011). 
1 Tufted or shortly rhizomatous, sympodial; spikelets awned, awn 6-12 mm long; callus hairs less than twice as long as the spikelets. M. sinensis 2 Rhizomatous, rhizome long; monopodial; spikelets awnless; callus hairs 2-4 times as long as the spikelets.

M. sacchariflorus

Miscanthus sinensis Andersson (syn. M. condensatus Hackel; M. flavidus Honda; M. purpurascens Andersson), also known as Chinese silver grass or Eulalia grass is native to southeastern Asia (EPPO 2011). It is used for ornamental purposes and is increasingly being planted as a crop for biofuel production. The species is rare garden escapee, occasionally naturalised on dumps or as a remnant of cultivation in some parts of the European continent (EPPO 2011). The aim of the article is to report the first record of the species in the Bosnia and Herzegovina.

\section{Material and methods}

Plants are tufted or shortly rhizomatous perennials. Culms erect, $50-300 \mathrm{~cm}$ tall, usually unbranched, glabrous or pubescent below the panicle. The ligule is semicircular, membranous, 1-3 mm long, margin ciliolate or dentate. Leaf blades are linear, flat, $3-20 \mathrm{~mm}$ wide and $16-80 \mathrm{~cm}$ long, margins serrulate, midrib white. The inflorescence is digitate with several branches, $10-40 \mathrm{~cm}$ long, and $8-28 \mathrm{~cm}$ wide. The panicle axis is subglabrous to pilose. Central inflorescence axis is 6-15 $\mathrm{cm}$ long. Rhachis tough; subterete; glabrous on surface. Rhachis internodes filiform; 4-8 mm long. Spikelets are in pairs. Fertile spikelets are pedicelled; 2 in the cluster. Pedicels are filiform; unequal; 1.5-6 mm long. The spikelets are 4-7 $\mathrm{mm}$ long, lanceolate, pilose or glabrous, awned; callus hairs 5-8 mm long, white
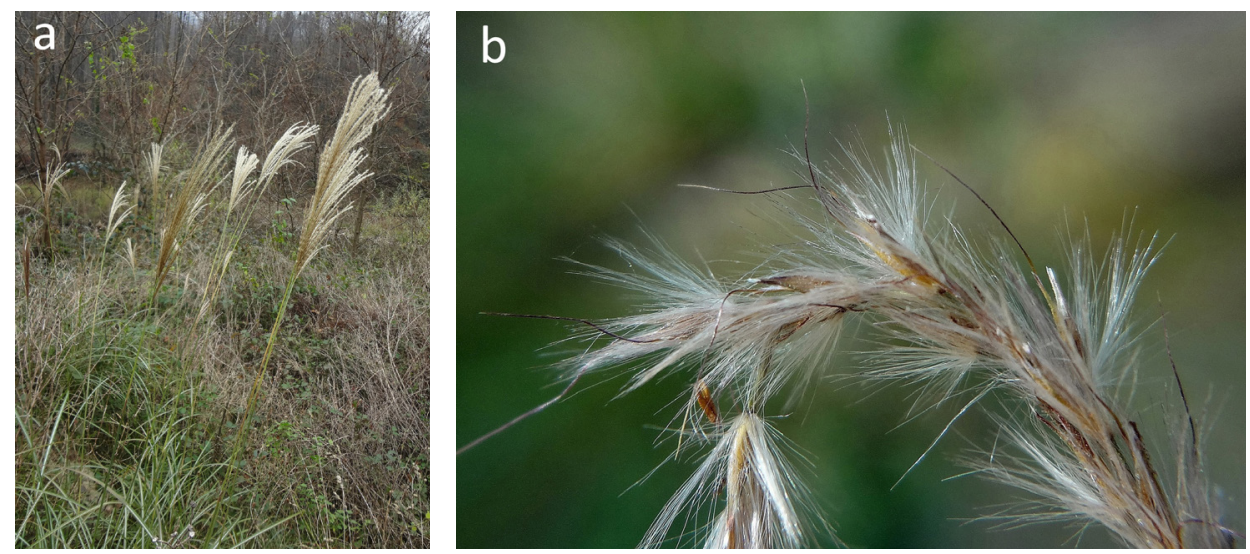

Fig.1 Miscanthus sinensis in the vicinity of the village Kovači near Zavidovići: $a-$ habitat $b-$ inflorescence (Photos by Šemso Šarić 2018) 
or yellowish, spreading, exceeding the spikelet. Glumes subequal, membranous, 4-6.5 mm, 5-veined, yellow to yellow-brown, back glabrous or pilose. The lower lemma lanceolate, hyaline, 3.5-4 $\mathrm{mm}$ long, veinless, apex and margins ciliate. Upper lemma 2.5-3.5 mm long, apex usually deeply two-toothed, margin ciliate: awn inserted between the teeth of the upper lemma, 4-12 $\mathrm{mm}$ long, brown, geniculate, upper part scabrid, lower part twisted when dry; upper palea lanceolate, 1-2 mm long, membranous, hyaline, apex ciliate. Anthers three, 1.5$3.0 \mathrm{~mm}$ long. Style 0.5-1.5 mm long with purple-black stigmas. Caryopsis 1.5-3.0 $\mathrm{mm}$ long, ellipsoid. Chromosome counts are $2 \mathrm{n}=35,36,38,40,41,57$ (Clayton et al. 2006; Shouliang \& Renvoize 2006; Sun et al. 2010).

The field study was conducted in the summer of 2018. Digital photographs and GPS coordinates were taken in the field. The identification of the specimens was done according to Walters et al. (1984), Sun et al. (2010) and Verloove (2011). The nomenclature follows Valdés \& Scholz (2009). The specimens were collected and stored in the Herbarium of the National Museum of Bosnia and Herzegovina (SARA, 51876, 51877).

\section{Results and discussion}

The first finding of $M$. sinensis to Bosnia and Herzegovina was recorded in Central Bosnia at two localities near the town of Zavidovići at the beginning of October 2018. First locality was situated near Maoča village $\left(44^{\circ} 18^{\prime} 2^{\prime \prime} \mathrm{N}\right.$; $18^{\circ} 24^{\prime} 5^{\prime \prime}$ E; elevation $345 \mathrm{~m}$ ). Here, the species was growing at the roadside on the right bank of Krivaja River about $10 \mathrm{~km}$ east of the town of Zavidovići. Second

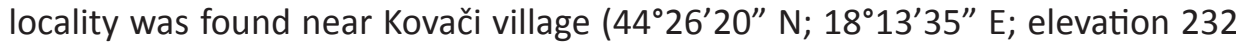
$\mathrm{m})$, where two minor populations were recorded each covering less than $5 \mathrm{~m}^{2}$.

$M$. sinensis reproduces primarily through rhizomes; however, it produces seeds that are mainly dispersed by wind. The gradual accumulation of $M$. sinensis seed in seed banks can contribute to successful local establishment of the species (Meyer 2003). The way of introduction is unknown, probably through garden waste because the species is quite often cultivated as ornamental plant in the area. The potential invasive behavior of the species should be monitored in the following years.

In Europe, escaped populations of $M$. sinensis have mostly been found in grassland and tall herb vegetations, at roadsides and different types of ruderal habitats. Most records have been collected in the Western and Central Europe: Austria, Belgium, Czech Republic, France, Germany, Great Britain, Italy, Netherlands, Spain and Switzerland. The species was first recorded in Italy 


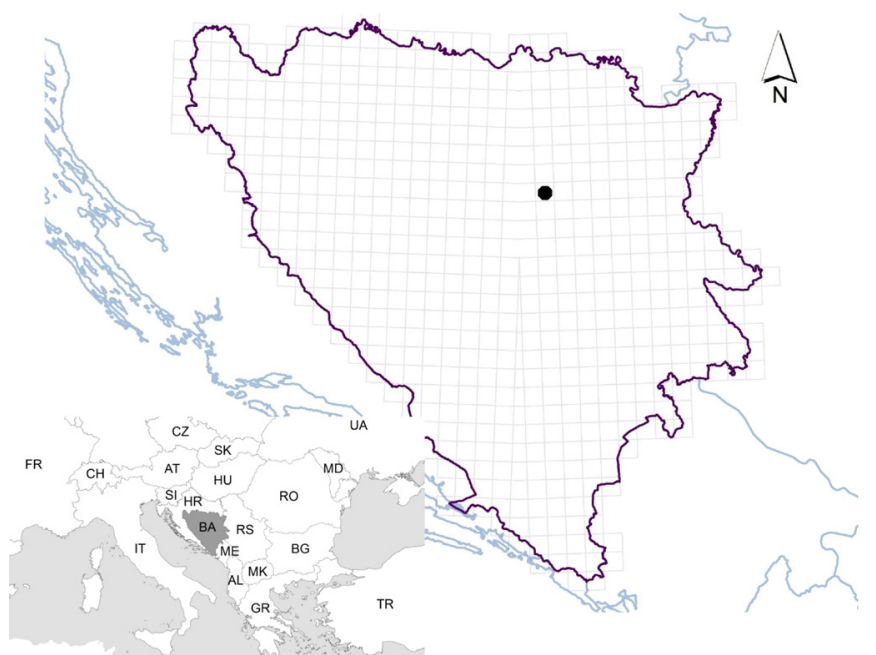

Fig. 2 The distribution of Miscanthus sinensis in the Bosnia and Herzegovina

(1902), and then later in France (1932) and Great Britain (1964) (Schnitzler \& Essl 2015). In the Balkans, M. sinensis was recorded only in Slovenia (Jogan 2007).

Originally introduced from Asia through the nursery trade $M$. sinensis is one of the most commonly cultivated ornamental grasses. Its ability to inhabit disturbed areas and its popularity as an ornamental species make it a serious threat to native flora. In the USA, it is considered as very common and invasive in some states (CABI 2018).

In comparison with the USA, the vast majority of the escaped populations in Europe were small (1-5 $\left.\mathrm{m}^{2}\right)$, but a few large populations have been already recorded in Italy and Germany (Schnitzler \& Essl 2015). Accordingly, in Europe, M. sinensis is listed on the EPPO Alert List of Invasive Alien Plants (EPPO 2011).

\section{Acknowledgements}

We would like to thank Aldin Boškailo (Mostar, Bosnia and Herzegovina) for mapping the distribution of the species and Jessica Andersson (Gislaved, Sweden) for improving the English of this paper.

\section{References}

CABI (2018): Miscanthus sinensis (eulalia) [original text by Riches, C.]. - In: Invasive Species Compendium. Wallingford, UK: CAB International (www. cabi.org/isc). [accessed October 2018]. 
Clayton W. D., Vorontsova M. S., Harman K. T. \& Williamson H. (2006): GrassBase -The Online World Grass Flora. http://www.kew.org/data/grasses-db.html [accessed Mars 2019].

EPPO (2011): Miscanthus sinensis (Poaceae) EPPO Alier list. Paris, France: European and Mediterranean Plant Protection Organization. https://www. eppo. int//ACTIVITIES/plant_quarantine/alert_list_plants/miscanthus_ sinensis [accessed October 2018].

Jogan N. (2007): Poaceae. - In: Martinčič A., Wraber T., Jogan N., Podobnik A., Turk B., Vreš B., Ravnik V., Frajman B., Strgulc Krajšek S., Trčak B., Bačič T., Fischer M. A., Eler K. \& Surina B. Mala flora Slovenije. Ključ za določanje praprotnic in semenk, 826-932. - Tehniška založba Slovenije, Ljubljana.

Meyer M. (2003). Fact Sheet and Management of Miscanthus sinensis. - University of Minnesota.

Schnitzler A. \& Essl F. (2015): From horticulture and biofuel to invasion: The spread of Miscanthus taxa in the USA and Europe. - Weed Res. 55: 221-225. https://doi.org/10.1111/wre.12141

Shouliang C. \& Renvoize S. A. (2006): Miscanthus. - In: Zhengyi W. \& Raven P. H. (eds.): Flora of China, vol. 22: 581-583. - Science Press, Beijing \& Missouri Botanical Garden Press, St. Louis.

Sun Q., Lin Q., Yi Z. L., Yang, Z. R. \& Zhou F. S. (2010): A taxonomic revision of Miscanthus s.l. (Poaceae) from China. - Bot. J. Linn. Soc. 164: 178-220. http://dx.doi.org/10.1111/j.1095-8339.2010.01082.x

Valdés B. \& Scholz H. (2009): Poaceae (pro parte majore). - In: Euro+Med PlantBase - the information resource for Euro-Mediterranean plant diversity [accessed October 2018].

Verloove F. (2011): Miscanthus Anderson. Manual of the Alien Plants of Belgium. - Botanic Garden of Meise, Belgium. At: alienplantsbelgium.be [accessed October 2018].

Walters S. M., Brady A., Brickell C. D., Cullen J., Green P. S., Lewis J., Matthews V. A., Webb D. A., Yeo P. F. \& Alexander J. C. M. (eds.) (1984): The European Garden Flora, vol. 2 (part II). - Cambridge University Press. 318 pp. 